\title{
Unscarred uterine rupture - rare entity
}

\section{Divya Pandey*, Neha Pruthi}

Department of Obstetrics and Gynaecology, VMMC and Safdarjung hospital, Delhi, India

Received: 24 July 2016

Accepted: 26 August 2016

\author{
*Correspondence: \\ Dr. Divya Pandey, \\ E-mail: dr_devya1@yahoo.co.in
}

Copyright: (c) the author(s), publisher and licensee Medip Academy. This is an open-access article distributed under the terms of the Creative Commons Attribution Non-Commercial License, which permits unrestricted non-commercial use, distribution, and reproduction in any medium, provided the original work is properly cited.

\begin{abstract}
Uterine rupture is a disastrous obstetric complication, with high rates of feto-maternal morbidity and mortality. The most frequent risk factor in present times is previous uterine surgery. We hereby report 3 cases of uterine rupture in unscarred uterus with varied presentation at different period of gestation so as to show the spectrum of clinical presentation of this entity. Quick recognition with prompt resort to laparotomy is crucial in influencing feto-maternal morbidity. All uterine ruptures don't present with classical symptoms. Thus, clinicians should have high index of suspicion for uterine rupture in women presenting with some, or all, of these features, regardless of parity or history of previous uterine surgery or parity.
\end{abstract}

Keywords: Unscarred, Rupture uterus, Spontaneous, Morbid adherent placenta

\section{INTRODUCTION}

Uterine rupture is an emergency associated with high feto-maternal morbidity and mortality. Besides, it can lead to loss of future fertility as hysterectomy may be inevitable in many cases. Four major easily identifiable risk factors include prior caesarean section, grand multiparty, obstructed labour and fetal malpresentations which account for $90 \%$ cases of uterine rupture. ${ }^{1}$

Spontaneous rupture of unscarred uterus without associated risk factors has been very scarcely reported in literature. Here we report three cases of uterine rupture in unscarred uterus in second and third trimester respectively.

\section{CASE REPORT}

\section{Case 1}

A 20-year old, unbooked, primigravida at 19 weeks presented to the tertiary care emergency with complaints lower abdominal pain for 8 hours which was continuous with increasing intensity, non-radiating, localised to umbilical and sub umbilical region and was not associated with discharge or bleeding per vaginum. Besides, there was no history of fever, vomiting and bladder/bowel complaints. The past medical, surgical or gynaecological history was unremarkable.

On examination, she had mild pallor with respiratory rate 20 per minute, pulse rate 98 per minute and blood pressure 110/60 mmHg. On abdominal examination her abdomen was soft but tender in lower part. Uterus was corresponding to 20 weeks, non-tense and with mild contractions. No vaginal bleeding was observed on speculum examination; however, there was marked tenderness on internal examination, os was closed and cervix was uneffaced. Conservative management in the form of intravenous fluids, antibiotics and analgesics (diclofenac, tramadol) was started, but there was no relief of pain. To rule out acute surgical causes, ultrasound abdomen was planned. As she was being evaluated for the cause of pain, she suddenly collapsed. There was severe pallor, her pulse increased to $118 / \mathrm{min}$, BP dropped to $70 / 56 \mathrm{mmHg}$, respiratory rate was $28 / \mathrm{min}$. On 
paracentesis there was hemoperitoneum and decision for emergency exploratory laparotomy was taken.

Emergency exploratory laparotomy was done with simultaneous resuscitation. Fetus along with placenta (Figure 1) was seen coming out of rent in cornua. There was 1.5 litres of hemoperitoneum. There was a $4 \mathrm{~cm}$ tear on the uterine fundus, $2 \mathrm{~cm}$ anterior to the cornua. Uterine tear repair was done. The myometrium adjacent to this was relatively thin. There was, however, no evidence of couvelier uterus or endometriosis. Patient received 4 units of blood and 4 units of FFP.

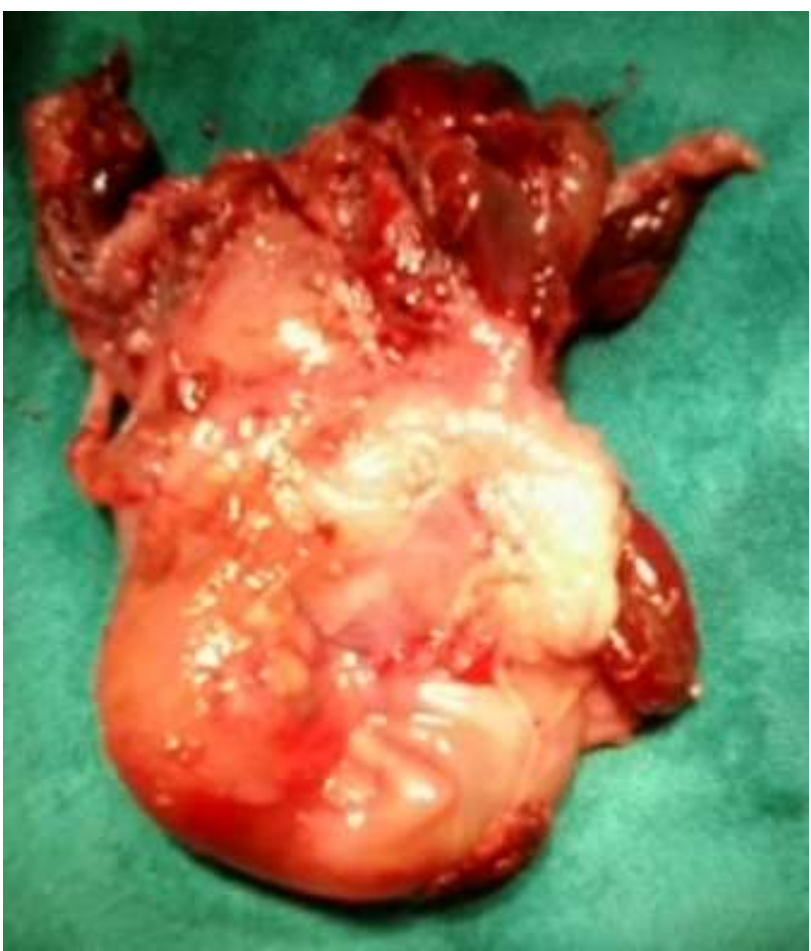

Figure 1: Fetus (black arrow) along with placenta which was seen lying in peritoneal cavity after spontaneous uterine rupture in case 1.

\section{Case 2}

A 22-year old female was referred to our hospital with diagnosis gravida 2, para1, live 0 with 38 weeks period of gestation with severe anemia, severe preeclampsia and intrauterine death. She had received 2 units of packed cells from the referral center. Her previous pregnancy was a full term normal vaginal delivery and baby expired at 9 months of age due to pneumonia. In the present pregnancy her chief complaints were; absent fetal movements for 4 days, leaking per vaginum for three days followed by bleeding per vaginum for one day. On examination, there was significant pallor (6 gm \% clinically), BP $170 / 110 \mathrm{mmHg}$, urine albumin $3+$ and pedal edema was present. Her oxygen saturation at room air was $98 \%$. On abdominal examination there was single fetus in breech presentation, fetal heart was not localized and uterus was non-tense and non-tender. On per vaginum examination, Bishops was 3 and there was no active bleeding. Ultrasound done showed dead fetus in breech with posterior placenta with retroplacental clot.

Patient received two units of packed cells were transfused, BP was controlled by anti-hypertensives, injection $\mathrm{MgSO} 4$ given and induction of labour in view of abruption placenta was started with tab misoprostol. After fourth dose patient started perceiving uterine contractions, however, she developed acute tenderness over lower abdomen and mild grade fever $\left(99^{\circ} \mathrm{F}\right)$. There was no improvement of bishop score and no bleeding per vaginum. In view of suspected chorio-amnionitis, she was taken up for emergency caesarean section. Incision was given on lower uterine segment and $3 \mathrm{~kg}$ macerated baby extracted as breech from uterine cavity, minimal blood stained liquor drained, cord was frail and it broke away. As there were no signs of placental separation, uterus was exteriorized and to our surprise placenta was seen extruding through rent in posterior wall of uterus. Placenta implanted partly on the posterior uterine wall, while majority was implanted on right broad ligament. No cleavage plane was seen, however, rent in uterus extending from uterus body to lower left posterior wall with shaggy margins was seen.

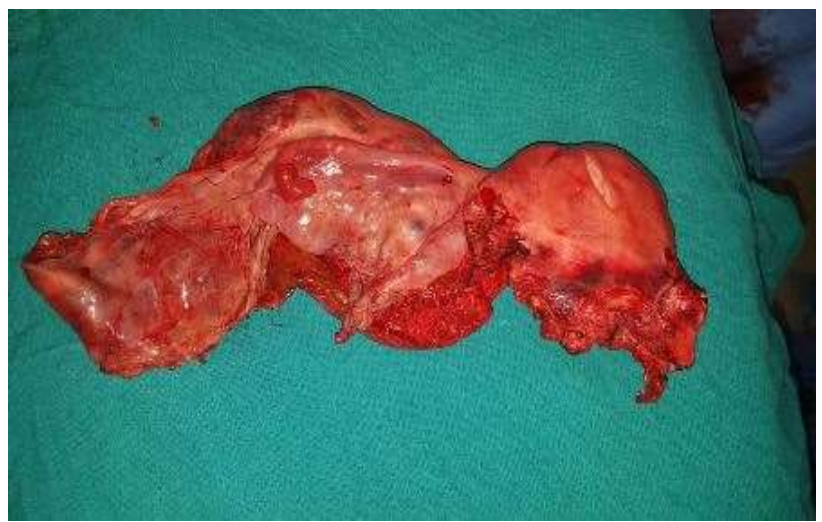

Figure 2: Specimen showing uterus ruptures due to associated placenta percreta in case 2 .

Subtotal hysterectomy with right salpingo-ophorectomy and right parametrectomy was performed (Figure 2). A total of 4 units packed cells and 6 units FFP were transfused. Placental membranes sent for culture showed growth of Enterobacter. Postoperatively patient had fever which responded to antibiotics and patient was discharged on day 15. Histopathology confirmed the diagnosis of placenta percreta with invasion into right broad ligament.

\section{Case 3}

A, 28 year old, unbooked, G2P1L1 female with term pregnancy with previous one normal delivery two years back presented to the tertiary care emergency after being referred from 2 centres in view of obstructed labour. At admission, the patient's condition was unstable and she 
did not perceive any uterine contractions. Her pulse was 116/min, BP90/60 mm Hg, RR-22/min. Per abdomen uterine contour was not maintained. Superficial fetal parts were palpable, FHS was not localised and there were no uterine contractions. On per vaginum examination, os was fully dilated, membranes were absent, no liquor drained, caput $1+$, vertex at +2 station. With provisional diagnosis of uterine rupture the patient was shifted to OT for immediate laparotomy. A $3.5 \mathrm{~kg}$ fetus was lying in the abdominal cavity along with placenta and there was approximately 1 litre of hemoperitoneum. The anterior wall of uterus was intact, but the posterior wall of uterus showed $7 \mathrm{~cm}$ rent in lower uterine segment extending till fundus (Figure 3 ). The tear was repaired by suturing the uterus in double layer. She received total of 4 units of blood and 4 units of FFP.

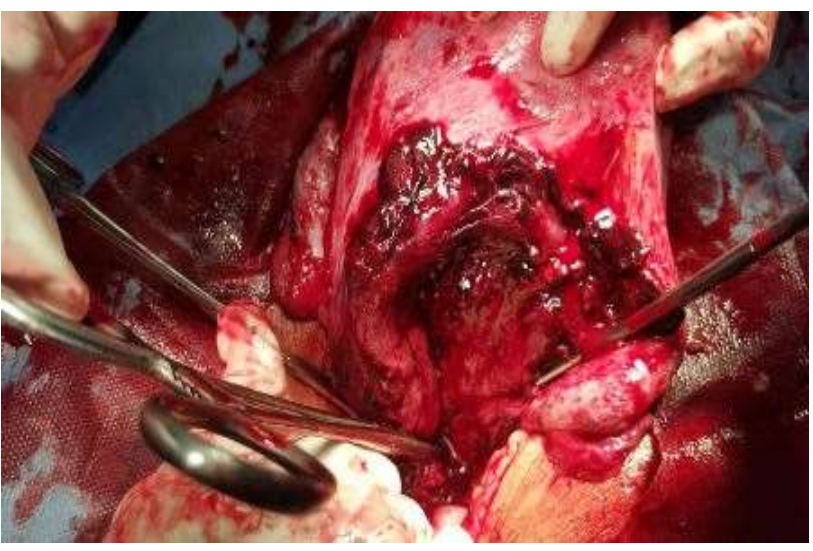

Figure 3: Intraoperative photograph of uterus rupture due to obstructed labour.

In all the cases, postpartum period was uneventful, stitch removal was done on the $7^{\text {th }}$ postoperative day and patients were discharged with advice for contraception for next three years and supervised subsequent pregnancy.

\section{DISCUSSION}

Rupture of the unscarred pregnant uterus is a rare event, estimated to occur in $1 / 5,700$ to $1 / 20,000$ pregnancies. $^{2-4}$ Uterine rupture is commonly seen in scarred uterus. ${ }^{5}$ Unscarred uterine rupture is rare, however, risk factors identified are multiparity, injudicious use of oxytocin, obstetric manoeuvres, chronic steroid use, Ehlers Danlos Syndrome, obstructed labour, uterine anomalies and abnormal placentation..$^{6-14}$ The high parity is recognised as a major risk factor for unscarred uterine rupture and majority of ruptures occur in term pregnancies at the time of labour. There have, however, been few case reports of uterine rupture in non-labouring patients.

Uterine ruptures in the first and second trimester are rare and few cases have been reported in literature. Uterine rupture in unscarred uterus has been reported to be mostly associated with uterine anomaly, however, a few cases with no previous risk factors were also identified. ${ }^{11,12}$ On literature search from PUBMED from 1990 till 2015 using MESH terms "unscarred uterine rupture", 13 cases in second trimester were identified. In majority ( 7 cases) abnormalities of placenta like placenta accreta, placenta percreta were identified as risk factors. Besides, uterine anomaly (3) and long term use of steroids (1) were also found to be associated with rupture. In two cases cause was not known. Our first case presented at 19 weeks. There was no history of long term steroid use or prior uterine instrumentation/ uterine surgery. At the time of surgery also, no uterine anomaly or placental abnormality was seen. Inherent weakness of myometrium was suspected to be the likely cause as mild contractions led to uterine rupture and thinning of myometrium was observed at the rupture site. In the second case, the cause of rupture was placenta percreta. The unusual thing in this case was the presence of morbid adherent placenta in an unscarred uterus. This also, can be attributed to congenital weakness of myometrium.

Ruptures in third trimester are most common and are seen in multigravida at the time of labour. If the labour is not monitored properly patients can land in obstruction which may lead to uterine rupture as was the case in our third patient. In the third case, patient reported late to the emergency with rupture. Most of the cases of obstructed labour are preventable. Early recognition and immediate intervention is important to prevent complications and improve maternal and fetal outcome.

The cases discussed above show extremes of presentation as the first case presented in early second trimester without labour pains in contrast to the third case who presented at term in labour. All the cases were managed aggressively and mothers were salvaged but fetus could not be saved. In the first case, early presentation and diagnosis could have helped us to do conservative surgery for the rent and achieve a successful pregnancy outcome as was done by Wang et al who repaired the rent at 21 weeks and delivered a live baby at 34 weeks by caesarean section. ${ }^{15}$ In the last case also, early reporting and timely intervention could have prevented patient from going into obstructed labour and subsequent rupture and fetal demise.

Clinicians handling the emergency should be sensitised that rupture uterus can present with non-specific signs and symptoms even in early trimesters.

\section{CONCLUSION}

Spontaneous unscarred uterine rupture although rare; can have a varied spectrum of presentation. It should always be kept in mind when a women reports with severe abdominal pain at early gestation or in late gestation with sudden loss of uterine contractions. High index of suspicion and timely interventions are required to prevent untoward feto-maternal outcome. 
Funding: No funding sources

Conflict of interest: None declared

Ethical approval: Not required

\section{REFERENCES}

1. Sinha M, Gupta R, Gupta P, Rani R, Kaur R, Singh R. Uterine Rupture: A Seven Year Review at a Tertiary Care Hospital in New Delhi, India. Indian J Community Med. 2016;41(1):45-9.

2. Dow M, Wax JR, Pinette MG, Blackstone J, Cartin A. Third-trimester uterine rupture without previous cesarean: a case series and review of the literature. Am J Perinatol. 2009;26(10):739-44.

3. Porreco RP, Clark SL, Belfort MA, Dildy GA, Meyers JA. The changing specter of uterine rupture. Am J Obstet Gynecol. 2009;200(3):269.e1-4.

4. Miller DA, Goodwin TM, Gherman RB, Paul RH. Intrapartum rupture of the unscarred uterus. Obstet Gynecol. 1997;89(5 Pt 1):671-3.

5. Veena $\mathrm{P}$, Habeebullah $\mathrm{S}$, Chaturvedula L. A review of 93 cases of ruptured uterus over a period of 2 years in a tertiary care hospital in South India. J Obstet Gynaecol. 2012;32(3):260-26.

6. Guèye M, Mbaye M, Ndiaye-Guèye MD, KaneGuèye SM, Diouf AA, Niang MM, Diaw H, et al. Spontaneous Uterine Rupture of an unscarred Uterus before Labour.Hindwai. 2012:598356.

7. Catanzarite V, Cousins L, Dowling D, Daneshmand S. Oxytocin-associated rupture of an unscarred uterus in a primigravida. Obstet Gynecol. 2006;108(3):723-5.
8. Noh JJ, Park CH, Jo MH, Kwon JY. Rupture of an unscarred uterus in a woman with long term steroid treatment for Systemic Lupus Erythematosus. Obstet Gynecol. 2013;122(2 Pt 2):472-5.

9. Rudd NL, Nimrod C, Holbrook KA, Byers PH. Pregnancy complications in type IV Ehlers- Danlos Syndrome. Lancet. 1983;1(8314-5):50-3.

10. Khooharo Y, Yousfani JZ, Malik SH, Amber A, Majeed $\mathrm{N}$, et al. Incidence and management of rupture uterus in obstructed labour.J Ayub Med Coll Abbottabad. 2013;25(1-2):149-51.

11. Mizutamari E, Honda T, Ohba T, Katabuchi H. Spontaneous rupture of an unscarred gravid uterus in a primigravid woman at 32 weeks of gestation. Case Rep Obstet Gynecol.2014:209585.

12. Kore S, Pandole A, Akolekar R, Vaidya N, Ambiye VR.Rupture of left horn of bicornuate uterus at twenty weeks of gestation.Journal of postgraduate medicine 2000;46(1):30-40.

13. Pierzynski P, Laudanski P, Lemancewicz A, Sulkowski S, Laudanski T.Spontaneous rupture of unscarred uterus in the early second trimester: a case report of placenta percreta. Ginekol Pol. 2012;83(8):626-9.

14. Blé RK, Adjoussou S, Doukoure B, Gallot D, Olou N, Koffi A, Fanny M, Koné M. Placenta percreta: A rare etiology of spontaneous uterine perforation in second trimester of pregnancy. Gynecol Obstet Fertil. 2011;39(1):e11-4.

15. Wang PH, Chao H T, Too L L, Yuan CC. Primary repair of cornual rupture occurring at 21 weeks gestation and successful pregnancy outcome. Hum Reprod. 1999;14(7):1894-5.

Cite this article as: Pandey D, Pruthi N. Unscarred uterine rupture - rare entity. Int J Reprod Contracept Obstet Gynecol 2016;5:3593-6. 